\title{
OUTBOUND DALAM PEMBELAJARAN BAHASA BALI PADA KELOMPOK BELAJAR ANAK-ANAK PENYULUH BAHASA BALI
}

\author{
Putu Pertama Yasa ${ }^{1}$ I Wayan Mandra ${ }^{2}$; I Nyoman Subagia ${ }^{3}$ \\ Universitas Hindu Negeri I Gusti Bagus Sugriwa Denpasar \\ Email: pertamay@gmail.com¹; wayanmandra@gmail.com² \\ nyomansubagia1182@gmail.com ${ }^{3}$
}

\begin{abstract}
Diterima tanggal 26 Januari 2021, diseleksi tanggal 10 Februari 2021, dan disetujui tanggal 27 Februari 2021
\end{abstract}

\begin{abstract}
Balinese language learning is generally carried out in three fields, namely formally, informally and non-formally. It is formally carried out at the school level starting from SD to SMA / SMK level, informally carried out in the family environment so that it is often referred to as the Mother Language, at this stage is the initial stage before the children learn formally in school. In the non-formal field, this can be done through courses which are usually carried out by certain institutions or organizations. Balinese language instructors who contribute to Balinese language learning non-formally develop methods or learning models with the concept of learning while playing, and bring learning to the surrounding environment or often called Outbound. As for the focus of this research are (1) the background of the emergence of the Balinese Language Outbound program (2) the form of the implementation of the Balinese Language Outbound (3) the implications of the implementation of the Balinese Language Outbound in the Learning group of SD Class V Balinese Language Instructors at Kalianget Village, Kec. . Seririt, Kab. Buleleng. The theories used to support this research are Behavioristic Learning Theory, Cognitive Learning Theory, Constructivism Theory.
\end{abstract}

Keywords: Outbound, Balinese Language Learning, Balinese Language Instructor

\begin{abstract}
ABSTRAK
Pembelajaran Bahasa Bali pada umumnya dilaksanakan pada tiga bidang, yaitu secara formal, informal dan non formal. Secara formal dilaksanakan dijenjang sekolah mulai dari tingkat SD hingga SMA/SMK, Secara informal dilaksanakan dilingkungan keluarga sehingga sering disebut sebagai Bahasa Ibu, pada tahap ini merupakan tahap awal sebelum anak-anak belajar secara formal disekolah. Pada bidang Non formal dapat dilakukan melalui kursus-kursus yang biasanya dilaksanakan oleh lembaga atau organisasi tertentu. Penyuluh Bahasa Bali yang berkontribusi dalam pembelajaran Bahasa Bali secara non formal mengembangkan metode-metode atapun model belajar dengan konsep belajar sambil bermain, dan
\end{abstract}


membawa pembelajaran kelingkungan sekitar atau sering disebut Outbound. Adapun yang menjadi fokus pada penelitian ini adalah (1) latar belakang munculnya program Outbound Bahasa Bali (2) bentuk pelaksanaan Outbond Bahasa Bali (3) implikasi dari pelaksanaan Outbond Bahasa Bali pada kelompok Belajar anak-anak SD Kelas V Penyuluh Bahasa Bali Desa Kalianget Kec. Seririt, Kab. Buleleng. Adapun teori yang dipakai untuk mendukung penelitian ini adalah Teori belajar Behavioristik, Teori Belajar Kognitif, Teori Konstruktivisme.

Kata Kunci: Outbound, Pembelajaran Bahasa Bali, Penyuluh Bahasa Bali

\section{PENDAHULUAN}

Perkembangan Bahasa Bali dapat dilihat dari usaha-usaha yang telah dilakukan pemerintah untuk meningkatkan pembelajaran Bahasa Bali, misalnya dengan Bahasa Bali sudah diajarkan dari sekolah dasar hingga sekolah menengah umum sebagai muatan lokal minimal 2 jam pelajaran dalam seminggu baik disekolah swasta ataupun negeri yang ada di Bali, bahkan dalam Revisi Perda Th 1992 tentang Bahasa, sastra dan aksara Bali yang kini menjadi Perda No 1 Th 2018 telah memungkinkan juga memasukan Mata Kuliah Bahasa Bali sebagai mata kuliah penunjang sesuai dengan kebutuhannya hal ini sudah jelas diatur dalam perda tersebut.

Tidak hanya dari segi regulasi dan aturan saja dalam perda diatur juga tentang pemberian pengghargaan kepada tokoh atau kelompok pemerhati Bahasa Bali yang selama ini secara iklas berkontribusi aktif untuk bahasa Bali dalam bentuk piagam dan uang penghargaan yang nominalnya cukup fantastis yakni paling sedikit seratus juta rupiah. Dalam perda juga sudah dimuat mengenai pengembangan buku pelajaran serta penelitian dalam bidang bahasa Bali.

Pembelajaran bahasa Bali pada umunya dilaksanakan pada tiga bidang, yaitu secara formal, informal serta non formal. secara formal dilaksanakan dijenjang sekolah mulai dari tingkat SD, SMP sampai dengan tingkat Menengah Atas atau SMA/SMK melalui Muatan lokal dengan durasi waktu dua jam pelajaran setiap minggunya, Secara informal dilaksanakan dilingkungan keluarga melalui komunikasi sehari-hari dengan anggota keluarga menggunakan bahasa Bali sehingga sering disebut sebagai bahasa Ibu dan tahap ini merupakan tahap awal sebelum anak-anak belajar secara formal disekolah. Pada bidang Non formal dapat dilakukan melalui kursus-kursus yang biasanya dilaksanakan oleh lembaga atau organisasi tertentu, namun hal ini sangat jarang dijumpai. Berbeda dengan kursuskursus bahasa Inggris ataupun bahasa Asing yang menjamur khususnya di Bali.

Keseruisan pemerintah dalam melestarian dan mengembangkan bahasa Bali baik dibidang formal, informal dan nonformal tampak jelas terutama dibidang Non formal. Hal ini bisa dilihat ketika Pemprov Bali merekrut dan penempatan tenaga Penyuluh Bahasa Bali dimasing-masing Desa Dinas di Bali yang bertujuan membantu pembelajaran secara formal yang dinilai masih kurang.

Keberadaan tenaga Penyuluh Bahasa Bali diharapkan dapat membantu permasalahan-permasalahan Bahasa Bali saat ini kususnya generasi muda dan anak-anak, selain itu membantu masyarakat dibidang pelestarian Bahasa Bali. Peran dan tugas penyuluhpun sangat diharpakan membantu pendidikan non formal yang telah ada, seperti pasraman-pasraman yang sudah berkembang selama ini di masyrakat, maupun dengan membentuk kelompok-kelompok belajar dari jenjang anak-anak, remaja dan dewasa. 
Penyuluh Bahasa Bali yang berkontribusi dalam pembelajaran bahasa Bali secara non formal mengembangkan metode-metode atapun model belajar dengan konsep belajar sambil bermain, dan membawa pembelajaran kelingkungan sekitar. Perlu kiranya sesekali mengajak para peserta didik belajar diluar kelas sangatlah penting. Selain untuk mengenal lingkungan sekitar akan menambah motivasi belajar mereka. Sebab anak-anak seperti diajak bermain dimana pada usia mereka sebagian besar masih senang bermain. Jika dikaitkan dengan era global kegiatan ini juga bisa disebut Outbond bahasa Bali.

Penelitian merupakan proses sistematik dalam mengembangkan dan menemukan pengetahuan yang benar dengan menyertakan contoh. Terdapat empat hal dibidang iptek menurut substansinya yaitu, kegiatan yang sistematik, pemanfaatan hasil, dan tindakan untuk menyebarkan temuan. Penelitian pada dasarnya dapat dibagi menjadi dua bagian yaitu kuantitatif dan kualitatif. Metode penelitian kuantitatif adalah jenis penelitian bentuknya sistematis, terstruktur dan terencana, dengan jelas mulai dari awal sampai pembuatan desain penelitian. Peneliitian kuantitatif merupakan penelitian dengan penggunaan angka, dari pengumpulan suatu data, hipotesa, dan dalam penampilan hasil penelitiannya. Biasaya berupa tabel, grafik sebagai tampilan hasil. Sugiyono (2012:7) mengemukakan cara mengambil sampel dilakukan secara acak, pengumpulan data menggunakan instrumen penelitian, analisis data pada umumnya bersifat kuantitatif'statistik dengan maksud menguji hipotesa yang dirumuskan sebelumnya.

Sedangkan penelitian kualitatif merupakan metode baru dikarenkan kemunculannya belum lama, metode ini juga disbut postpositivistik sebab berlandas pada filsafat post positifisme, serta sebagai sebuah metode artistik karena dalam penelitiannya tidak terpola, Hasil penelitian disajikan dengan interprestasi dengan data-data di lapangan

Metode penelitian kualitatif disebut juga sebagai metode penelitian yang natural dikarenakan penelitian dilakukan secara alamiah. Metode ini dikenal juga sebgai metode etnographi, sebab pada awalnya banyak digunakan dalam bidang penelitian bidang antropologi budaya. Bogdan dan Taylor (Moleong 2004:3) menyatakan metode kualitatif adalah penelitian yang disajikan dalam data deskriptif secara lisan, berbentuk kata-kata terhadap apa yang telah diamati

Fokus penelitian ini adalah bagaimana pelaksanaan Outbound Bahasa Bali pada kelompok belajar anak-anak penyuluh Bahasa Bali untuk meningkatkan semangat belajar dan pemahaman anak-anak pada Bahasa Bali. Oleh sebab itu penelitian ini menggunakan jenis penelitian kualitatif.

Penelitian ini berlokasi pada kelompok belajar yang dilaksanakan oleh penyuluh Bahasa Bali yang bertugas dimasing-masing Desa/kelurahan. Mengingat luasnya wilayah penelitian tersebut maka peneliti memutuskan untuk mengambil lokasi penelitian dikabupate Kabupaten Buleleng, tepatnya di Desa Kalianget Kecamatan Seririt hal ini berdasarkan pengamatan penulis bahwa kelompok belajar didesa tersebut sebagai pilot projet program Outbound. Bahasa Bali, penyuluh didesa tersebut sebagai salah satu tim penggagas pelaksanaan out bound diwilayah kabupaten Buleleng. Populasi keberadaan penyuluh di Kabupaten Buleleng paling banyak dibandingkan dengan kabupaten lain di Bali. disatu sisi Buleleng sering disebut sebagai kota pendidikan hal ini terntu menjadi pertimbangan lainnya. Jumlah penyuluh Bahasa Bali di kabupaten Buleleng sebanyak 148 Orang, maka tentu populasi jumlah kelompok belajar yang dimiliki juga sangat banyak. 
Menurut Anzwar (2005: 118) mengemukakan "data adalah hasil pencatatan peneliti, baik yang merupakan angka maupun fakta Kualitatif yang berhubungan dengan katagorisasi, karakteristik, berwujud pemyataan atau berupa kata-kata". Mengingat penelitian ini menggunakan deskripsi jadi jenis penelitian ini yang berjudul Penerapan Pembelajaran out boud Bahasa Bali studi kasus Kelompok belajar anak-anak Penyuluh Bahasa Bali menggunakan jenis data kualitatif

Bungin (2001: 123) menyatakan data merupakan penjelasan mengenai satu obyek. Dalam penelitian kualitatif data penelitiannya bersifat langsung. Sumbersumber yang terkait dengan penelitian tersebut. Berdasarkan sumber pengambilannya, data dibedakan dalam dua jenis yakni, data primer dan data sekunder.

1. Data Primer merupakan data berupa wawancara langsung dari kelompok atau orang dalam bentuk jajak pendapat, observasi sebuah kejadian langsung dari sumber asli. Artiya peneliti memerlukan pengumpulan data dengan langkah menjawab pertanyaan riset (metode survel) atau penelitian benda (metode observasi). Igbal (2002:167) data primer merupakan data yang didapat secara langsung dilapangan oleh peneliti atau orang yang membutuhkannya, data primer juga disebut data asli. Dalam penelitian ini yang termasuk data primer adalah hasil wawancara dari Penyuluh Bahasa Bali, dan anak-anak peserta kelompok belajar.

2. Data Sekunder Data sekunder merupakan data yang didapat melalui perantara tidak langsung dari buku, catatan, arsip yag telah ada. Peneliti biasanya mendapatkannya dari perpustakan, pusat kajian atau bacaan yang berhubungan dengan penelitiannya. Data ini bisaanya didapat dari laporan-laporan penelitian sebelumnya, atau perpustakaan. Pada penelitian ini. yang termasuk kedalam data sekunder adalah Buku pedoman penyuluh Bahasa Bali dan Bahan ajar yang digunakan.

Alat khusus yang digunakan dalam mencari dan medapatkan data disebut dengan metode pengumpulan data. Dalam penelitian ini menggunakan data primer, Data primer merupakan data langsung dari sumber subjek penelitian. Dalam penelitian ini yang dimaksud dengan data primer adalah hasil wawancara dari para informan.

Observasi Suatu cara dalam pengumpulan data dengan pengamatan suatu objek, diiringi dengan pencatatan sebuah keadaan, ataupun prilaku disebut dengan Observasi. Metode yang dipakai dalam penelitian ini adalah non partisipan karena peneliti tidak langsung terlibat langsung dengan objek yang diteliti, namun banya sebagai pengamat independen.

Studi kepustakaan merupakan seluruh kegiatan peneliti dalam mengumpulkan informasi yang sesuai dengan topik permasalahan yang diteliti. Informasi tersebut bisa didapat bersumber pada buku-buku ilmiah, laporan peneliti sebelumya, karangan ilmiah, skripsi, tesis dan disertasi, peraturan, ensiklopedia, dan sumber-sumber lainnya yang tertulis atau digital.

kepustakaan adalah proses yang tidak dapat dipisahkan dalam sebuah penelitian. Teori-teori yang menjadi permasalahan dalam bidang yang akan diteliti bisa ditemukan melalui studi kepustakaan. disamping itu peneliti bisa mendapat informasi mengenai penelitian-penelitian sejenis atau yang berkaitan dengan penelitiannya dan penelitian-penelitian yang sudah dilakukan sebelumnya. Melalui studi kepustakaan, peneliti bisa memanfaatkan semua informasi dan pemikiranpemikiran yang sesuai dengan penelitiannya Studi kepustakaan dilakukan dalam 
penelitian ini untuk memperoleh informasi yang lebih akurat sesuai dengan obyek penelitian.

Wawancara merupakan sebuah cara atauteknik dalam menggali atau mendapatkan sebuah informasi pada umumnya dilakukan oleh wartawan. Dalam sebuah proses mendapatkan sebuah berita wawancara adalah proses yang sangat penting. Dengan demikian, bagaimana tehnik yang baik dan benar haruslah dikuasai oleh scorang wartawan. Wawancara merupakan sebuah proses dalam menggali sebuah informasi tertentu didapat secara langsung dari. Melalui narasumber langsung akan didapat sebuah informasi yang diperlukan secara benar adanya. Jika kita mampu dalam melaksanakan sebuah wawancara dengan teknik yang baik dan benar.

Informasi-informasi inilah yang akan diolah, ditafsirkan dan dianalisis oleh peneliti menegenai data yang didapat. Dalam penelitian ini wawancara dilakukan dengan terbuka/langsung kepada Anak-anak peserta kelompok belajar penyuluh Bahasa Bali.

Sebuah cara dalam mengolah suatu data menjadi informasi dengan tujuan agar data tersebut lebih dipahami, menjadi bermanfaat untuk menemukan jalan keluar dari permasalahan dalam penelitian maka diperlukan tehknik analisis data. Analisis data adalah suatu bentuk kegiatan dalam merubah dari data hasil suatu penelitian menjadikan sebagi informasi yang selanjutnya dapat dipakai landasan dalam mengambil suatu kesimpulan. Analisis data juga bisa dsisebut proses kegiatan menelaah semua hasil data penelitian yang didapat dengan observasi, pencatatan suatu dokumen, dan sebagainya, Analisis data yang dilakukan dengan analisis kualitatif yang bersifat deskriptif. Seperti menurut Koentjaraningrat (2010:174) mengatakan "metode deskriptif adalah suatu metode yang memperoleh data secara tersusun dan sistematis schingga memperoleh suatu kesimpulan" Jika data sudah disimpulkan ataupun diolah selanjtunya dibuatkan analisa, kemudian bisa ditarik kesimpulan yang bermanfaat bagi penelitian guna mengambil keputusan atau kesimpulan. Metode deskriptif merupakan metode yang dipakai dalam analisis penelitian ini.

\section{PEMBAHASAN}

\subsection{Latar belakang munculnya program Outbond Bahasa Bali}

Secara internal Minat dan Bakat Belajar Bahasa Bali anak-anak Desa Kalianget sangat minim, Meskipun Mata Pelajaran Bahasa Bali Telah dicantumkan dalam setiap kurikulum disekolah, namun hal ini belum mampu mengatasi permasalahan-permasalahan yang ada di Desa kalianget, Jro Bendesa Kalianget I Nyoman Suparta saat ditemui untuk wawancara pada tgl 30/7/2020 mengatakakan.

"sekarang ini sulit mencari potensi dibidang Bahasa Bali terutama dikalangan remaja dan anak-anak, terutama untuk regenerasi Sekaa santhi, apalagi yang mahir menulis aksara Bali, lebih-lebih dibidang nulis lontar."

Pegiat dan Pelaku Sastra Bali, Penulis Lontar serta Pewara Bahasa Bali, MC atau Ugrawakia dan masih banyak permasalahan lainnya. Hal ini dikarenakan Rendahnya minat Belajar dibidang Bahasa, Aksara dan Sastra Bali anak-anak di Desa Kalianget. Pihaknya selalu kesulitan dalam mencari bakat-akat dibidang sastra Bali, terutama dalam upaya pembinaan dan kegiatan-kegiatan yang sifatnya mewakili Desa. Minimnya kelompok penggiat atau pemerhati Bahasa di desa kalianget juga sudah sedikit, terutama yang diikuti oleh anak-anak muda dan remaja 
yang ada hanya kelompok tari atau sanggar. Kondisi ini terlihat jelas ketika Pihak Desa Adat tidak bisa mengirim perwakilan atau Duta Desa dalam lomba Masatua Bali dan Pidarta Bahasa Bali dalam acara Festival seririt Budaya pada tahun 20017 yang lalu yang diselenggarakan oleh Pemerintah Kec. Seririt.

Desa adat kalianget juga telah berupaya menyelenggarakan pasaraman anakanak dan remaja sebagai upaya pembinaan sejak dini. Namun pasraman tersebut tidak bisa berjalan maksimal karena hanya bisa dilangsungkan secara kilat akibat anggaran pembiayaan yang terbatas. Pembiayaan tersebut diambil dari dana BKK Provinsi Bali yang diberikan setiap tahunnya tanpa ada dukungan dari sponsor, pengusaha maupun swadaya masyarakat Desa adat.

Penyuluh Bahasa Bali yang bertugas dimasing-masih Desa dan Kelurahan sejak bulan Juni 2016 telah dibekali dengan berbagai program kerja yang telah disusun melalui buku panduan. Program-program akan dilaksanakan menyasar berbagai kalangan masyarakat, mulai dari tingkat anak-anak, remaja hingga dewasa. Namun yang menjadi perhatian khusus adalah pada kalangan anak-anak yang menjadi langkah awal sebagai target pembinaan dengan membentuk kelompok belajar dimasing-masing Banjar

\subsection{Faktor Eksternal}

\section{Keluarga, Lingkungan dan Masyarakat}

Penggunaan Bahasa Bali dalam ranah pendidikan informal menjadi hal yang paling penting sebagai dasar anak-anak dalam menerima pendidikan Bahasa Bali lebih lanjut di jenjang sektor pendidikan formal dan nonformal. Lingkungan Keluarga dalam hal ini berperan penting dalam mengawali anak-anak untuk belajar Bahasa Bali, sehingga sering disebut bahwa Bahasa Bali sebagai Bahasa Ibu.

Pemerintah Provinsi Bali melalui perda no 1 tahun 2018 Bab 3 juga sudah mengatur lebih lanjut mengenai penggunaan Bahasa Bali yakni sebagai sarana komunikasi dilingkungan keluarga, komunikasi dalam segala kegiatan agama Hindu, Adat dan Budaya Bali, kemudian pemberian informasi pada layanan masyarakat sebagai pendamping Bahasa Indonesia, secara khusus juga diatur sebagai sarana komunikasi oleh pegawai, guru, tenaga pendidik, masyarakat dan lembaga pemerintah maupun swasta pada setiap hari kamis, purnama dan tilem serta pada hari jadi Provinsi Bali.

Tujuan dari regulasi perda tersebut jelas agar penggunaan Bahasa Bali mendapatkan ruang yang lebih banyak yang semakin hari kian ditinggalkan oleh penuturnya terutama dikalangan Keluarga dibali khususnya di Desa Kalianget. Meskipun demikian masyarakat masih saja beranggapan Bahasa Bali itu kuno, hal ini terjadi pada sebagaian masyarakat Desa Kalianget mereka gengsi berbahasa Bali, terutama ibu-ibu muda yang baru mempunyai anak satu atau dua, mereka berkomunikasi dengan anak menggunakan Bahasa Indonesia pernyataan tersebut disampaikan oleh Kelian Desa Adat Kalianget I Nyoman Suparta yang ditemui pada saat wawancara tgl 30/7/2020 mengatakakan:

"Ibu-ibu sekarang lebih cendrung menggunakan Bahasa Indonesia berbicara dengan anaknya, terutama ibu-ibu muda, sering saya lihat saat berbicara di Pura saat odalan, Suba di Pura nu masi Bernesia, gengsi lebian( sudah di Pura masih juga berbahasa Indonesia, gengsi sepertinya" 


\section{Bahan Pelajaran dan Fasilitas}

Refrensi buku dibidang Bahasa, Sastra dan Aksara Bali untuk jenjang pendidikan SD saat ini masih sangat sedikit, seperti buku satua, tata bahasa dan pedoman menulis Bali. Buku pedoman yang digunakan oleh sekolah hanya berupa Buku paket, akan tetapi banyak materi-materi yang terkadang dinilai masih terlalu sulit untuk anak-anak SD, dan setiap sekolah terkadang tidak menggunakan refrensi yang sama.

Tokoh Bahasa Bali seperti Bapak Wayan Simpen A.B, dan I Nengah Tinggen telah banyak membuat buku-buku Pedoman, satua dan Kamus Bahsa Bali, namun sangat jarang digunakan sebagai Refrensi tambahan oleh Sekolah. Karya Beliau sesungguhnya sangat bermanfaat sebagai penunjang proses pembelajaran dan pemahaman anak-anak dibidang Bahasa Bali. Karya-karya beliau saat ini memang sudah jarang lagi diterbitkan oleh percetakan.

Kondisi tersebut telah dipahami oleh Penyuluh Bahasa Bali yang bertugas didesa dan membina Kelompok Belajar. Salah satu penyuluh Bahsa Bali juga membuat Buku saku sebagai pedoman sederhana untuk belajar Bahasa Bali. Seperti yang dijelaskan oleh Ketut Sidang Partayasa saat diwawancara pada hari Kamis 25/7/2020 mengatakan:

"Anak-anak jarang punya buku pedoman untuk Belajar Bahasa Bali, Sehingga perlu difasilitasi untuk dianggarkan oleh pemerintah Desa melalui Dana Desa"

Pemanfaatan dana desa dalam hal ini memang sangat efektif membantu bidang pendidikan terutama disektor nonformal, hal ini dilakukan oleh Pemerintah Desa Kalianget yang telah memfasilitasi Kebutuhan dan penunjang kegiatan Kelompok Belajar Bahasa Bali di Desa Kalianget.

Selain buku dan bahan pelajaran terdapat permasalah lain yaitu Guru Kelas yang mengajar Bidang studi Bahasa Bali. dan hal ini memang terjadi hampir disemua Sekolah Dasar di Seluruh Buleleng (data terlampir). Kepala Seksi Guru dan Tenaga Pendidik Sekolah Dasar Dinas Pendidikan kepemudaan dan Olahraga Kab. Buleleng Bapak Ketut Suardika saat diwawancara pada hari Selasa 2/9/2020 mengatakan

"Standar pendidikan untuk SD saat ini Bahasa Bali termasuk Muatan Lokal dalam Kurikulum sehingga belum ada Secara khusus Guru Bidang Studi yang mengajarnya, kebanyakan diajar oleh Guru Kelas dan Guru Agama"

Keadaan seperti ini berpengaruh terhadap kemampuan anak-anak dalam menguasai ketrampilan Bahasa Bali, Guru kelas hanya bisa mengajarkan semampunya mereka seperti yang disampaikan oleh Guru Kelas V SD N 2 Kalianget Ibu Putu Eka Budianyani saat diwawancara pada Senin 7/9/2020

"kendala utama dalah saat mengajar aksara Bali, terutama saat mengajar pasangaksara,"

Anak-anak kadang juga merasa tertekan saat belajar bahasa Bali, takut dihukum saat salah dan akhrinya situasi belajar menjadi kurang menyenangkan, Padahal pada jenjang Sekolah Dasar ini seharusnya pemahaman awal untuk menanamkan kecintaan terhadap Bahasa Bali, pada jenjang ini anak-anak harus di ajarkan secara serius ketrampilan Bahasa Bali terutama membaca dan menulis agar di Jenjang yang lebih tinggi mereka bisa menggembangkannya.

Kehadiran Tenaga Penyuluh Bahasa Bali yang ditempatkan di masingmasing Desa Kelurahan di Bali mendapat sambutan baik dari Guru-guru kelas di 
Sekolah Dasar yang ada di Desa-Desa, terlebih mereka mempunyai program kelompok belajar yang dalam hal ini pesertanya dari kalangan anak-anak, salah seorang guru Kelas V SD N 1 Kalianget Bpk Made Ardana saat diwawancara hari jumat 11/9/2020 menyampaikan bahwa:

"Guru disekolah sangat dibantu dalam hal pengembangan kemampuan Bahasa, Sastra dan Aksara Bali, ya bersyukur ada penyuluh Bahasa Bali yang mengadakan jam tambahan diluar sekolah.

Terlebih sekolah yang kemampuan guru kelasnya sangat minim dibidang Bahasa Bali mereka menyambutnya dengan sangat atusias.

\subsection{Bentuk Pelaksanaan Outbound Bahasa Bali pada kelompok belajar anak-anak SD kelas V Penyuluh Bahasa Bali Desa Kalianget Kec. Seririt, Kab. Buleleng \\ Tujuan Pembelajaran}

Tujuan dari sebuah proses pembelajaran outbond bahasa Bali pada Kelompok Belajar anak-anak SD Kls V penyuluh Bahasa Bali Desa Kalianget adalah:

1. Peserta mampu berbicara dengan menggunakan bahasa Bali kepada orang Tua, Teman, dan lingkungan sekitar dengan penuh percaya diri.

2. Peserta mapu membaca dan menulis Aksara Bali dengan baik dan benar

3. Peserta mampu membuat dan mengusai jenis-jenis Bashita Paribhasa Bali serta menggunakannya dalam kehidupan sehari-hari.

4. Peserta mampu mengusai jenis-jenis sastra tradisional dan moderen.

5. Peserta mampu mengikuti apresiasi dalam bentuk lomba-lomba yang diadakan dalm setiap kesempatan oleh lembaga swasta atau pemerintah yang berkaitan dengan Bahasa, sastra dan Aksara Bali.

\section{Materi Pembelajaran}

Bentuk Pelaksanaan Outbond Bahasa Bali yang kedua yaitu belajar meningkatkan ketrampilan berbahasa Bali khususnya Berbicara dan Menyimak menggunakan materi Basita Paribhasa dengan sistem kelompok. Basitha Paribasa dalam bahasa Indonesia disebut dengan Pribahasa. Basitha Paribasa terdiri dari beberapa jenis yaitu: Cecimpedan, Bladbadan, Wewangsalan, Peparikan, Sesonggan, Sesimbing, Sloka, Sesenggakan, Pepindan, Ceangkriman, Cecangkitan, Raos ngmpelin, Sipta, Tetingkesan, Sesapan, Sesawangan. Dari berbagai jenis Basitha Paribasa tersebut yang lebih banyak diajarkan adalah yang sering digunakan dalam kehidupan sehari-hari seperti: Cecimpedan, Wewangsalan, Bladbadan dan Raos ngempelin

Secara umum kegiatan menyimak sering dianggap membosankan bagi anakanak, begitu juga dengan Berbicara sering menjadi kendala. Pembelajaran Basitha Paribhasa membuat peserta lebih aktif dalam berbicara dan lebih serius dalam menyimak. Peserta Outbond akan belajar berpikir kritis, dan menganalisis, dengan demikian secara otomatis semakin menambah kosa kata Bahasa Bali. Setiap kelompok peserta Outbound wajib membuat Basitha Paribasa yang akan dibawakan kepeserta kelompok yang lain, tugas kelompok yang lain adalah menjawab Basitha Parbhasa tersebut, dalam hal ini peserta berusaha mengeluarkan Basitha Paribhasa sesulit munngkin agar tidak bisa dijawab oleh kelompok lain. Apabila berhasil dijawab akan diberikan score dan giliran Kelompok tersebut 
mengeluarkan Basitha Paribhasa. Penyuluh Bahasa Bali menjadi fasilitator dalam kegiatan ini sekaligus memberikan scor penilaian.

\section{Metode pembelajaran}

Salah Satu metode yang digunakan dalam pelaksanaan pembelajaran Outbond bahasa Bali adalah dengan tehnik dolanan. Dolanan merupakan permainan khas anak-anak dibali yang sudah ada secara turun temurun. Bentuk yang ketiga ini diaplikasikan dalam penguatan belajar Kasusastraan Bali, baik itu sastra Bali moderen atau sastra Bali tradisional. Derasnya kemajuan teknologi memunculkan berbagai macam permainan-permainan yang bersifat modern, online yang erat kaitanya dengan Gadgade membuat Dolanan kian ditinggalkan, serta Sastra lisan yang semakin jarang diajarkan dimasyarakat menjadi salah satu alasan konsep Dolanan ini diperkenalkan.

Peserta Outbound dibagi menjadi tiga kelompok dan masing-masing akan menampilkan permanian. Permainan yang ditampilkan berupa dalam bentuk rnyayian tembang rare atau membawakan sebuah satua, membaca cerpen maupun puisi. Materi-materi yang dibanyak diajarkan dalam Dolanan ini adalah permainan yang mengandung unsur pendidikan, budaya dan permainan tradisonal. Konsep dolanan yang ditampilkan bisa bersifat rekreatif, kompetitif dan Edukatif. Bentuk ini melatih anak-anak untuk bekerjasama sebagai anggota kelompok, dan belajar melatih kecakapan dalam berinteraksi dan membantu perkemabangan psikologis anak. Permainan dolanan juga dapat membantu melatih fisik dan menjaga kesehatan jasmani anak-anak karena banyak melakukan gerakan fisik. ni Setiap kelompok yang tampil wajib mengungkapkan pesan yang terkandung didalamnya. Dengan konsep dolanan anak-anak akan lebih mudah untuk mengingat materi yang diajarkan terutama dibidang sastra lisan, seperti sekar rare dan permainan tradisional yang bersifat kearifan lokal dan secara tidak langsung mengajarkan niliai-nilai pendidikan karakter. Anak-anak dalam situasi riang gembira saat mengikuti pembelajaran dengan konsep Dolanan karena konsep ini merupakan konsep belajar sambil bermain.

\section{Media pembelajaran}

Media yang digunakan dalam pelaksanaan pembelajaran Outbond Bahasa Bali yang adalah menggunakan Media pembelajaran Puzzle Aksara Bali. Puzzel ini berbentuk Huruf Bali sesuai dengan jumlah Aksara Bali yang ada yakni, 18 Aksara Wianjana (konsonan) lengkap dengan gantungan dan gempelan, Aksara Suara (vokal) dan Pengangge tengenan serta tanda baca. Aksara-aksara tersebut bisa terbuat dari bahan Kayu, triplek ataupun kertas. Pada Setiap Bagian aksara tersebut diisi perekat yang nantinya bisa ditempelkan pada papan yang disiapkan. Papan perekat aksara tersebut berbeda dengan papan tulis pada umumnya, papan ini dibuat secara khusus agar aksara atau puzzle bisa ditempelkan. Bahanya dibuat dari triplek dan dilapisi dengan karpet, ukuranyapun dibuat lebih kecil dari papan tulis pada umunya serta bisa dilipat sehingga mudah dibawa ketempat pelaksanaan kegiatan outbond.

Media ini puzzle ini dugunakan untuk Belajar Menulis, dan membca akasra Bali. Membaca dan menulis Aksara Bali menjadi kesulitan bagi sebagian besar anak-anak peserta Kelompok Belajar di Desa kalianget. Anak-anak selalu kesulitan dalam menghafal bentuk-bentuk Aksara Bali, baik itu Pengangge suara, 
Pengangge tengenan, gempelan dan gantungan.. Setiap peserta mendapatkan kesempatan untuk merangkai Kata atau kalimat dalam Aksara Bali. Peserta secara bergiliran menyusun sebuah kata atau kalimat yang diberikan oleh penyuluh Bahasa Bali. Materi yang diberikan berupa menulis nama-nama binatang, buah-buahan, dan kalimat mengenai aktivitas sehari-hari. Apabila peserta mampu menyusun atau merangkai kata dalam puzzle Aksara Bali akan mendapat skor, namun jika salah tidak mendapatkan score selanjutnya dialihkan ke kelompok peserta yang lain. Dengan Puzzel ini para peserta lebih cepat untuk mengingat bentuk-bentuk aksara Bali.

\section{Evaluasi pembelajaran}

Evaluasi pembelajaran dilakukan secara berkala, sitem reward dan punishment diterapkan saat pelaksanaan pembelajaran Outbond. Reward atau hadiah diberikan kepada kelompok peserta yang menjadi pemenang, sedangkan hukuman diberikan kepada mereka yang kalah dalam permainan. Pemberian reward atau hadiah memberikan motivasi lebih kepada anak-anak peserta Outbond. Sedangkan Hukuman adalah hal-hal yang dihindari oleh peserta, dengan demikian para peserta akan berkompetisi secara sehat.

Pemberian reward dan punishment tidak lepas dari hal-hal yang positif yang tentunya dapat menambah motivasi peserta dalam mengikuti kegiatan Outbond bahasa Bali. Reward biasanya berupa alat-alat tulis, makanan ringan dll, yang sumbernya dari Anggaran Pemerintah Desa Kalianget, sedangkan hukuman biasanya berupa menggendong teman, atau bernyanyi lagu-lagu bali.

Penyuluh Bahasa Bali sebagai pengajar bertugas memberikan score atau penilaian saat kegiatan pembelajaran Outbond berlangsung, mencatat dan melaporkan semua perkembangan Peserta kepada Kepala desa selaku penanggung jawab kegiatan, selain itu laporan juga sampaikan kepada masing-masing Kepala Sekolah guna memberikan gambaran perkembangan siswa saat mengikuti Kegiatan diluar sekolah dalam hal ini adalah kegiatan Outbond bahasa Bali.

\subsection{Implikasi dari pelaksanaan Outbond Bahasa Bali pada Kelompok Belajar Anak-anak SD Kelas V Penyuluh Bahasa Bali Desa Kalianget Kec. Seririt, Kab. Buleleng.}

Implikasi dari pembelajaran dengan konsep Outbound tidak terlepas dari tujuan pokok pembelajaran yang meliputi tiga bidang yaitu; Afektif, Kognitif, dan Psikomotor. Perkembangan tiga komponen tersebut tentu diharapakan secara bertahap dan merarata melalui pembelajaran yang sudah diterapkan. Oleh sebab itu Secara keseluruhan diharapkan akan meningkatkan kemampuan siswa pada bidang Bahasa, Sastra dan Aksara Bali Khususnya pada anak-anak SD Kls V dilingkungan Desa Kalianget.

Perkemabangan dan perubahan sikap, pengetahuan dan ketrampilan anakanak SD kls V Desa kalianget sebagai peserta Outbound dapat dilihat dari tiga bidang yaitu Bahasa, Sastra dan Aksara Bali. Selain tiga bidang tersebut, juga bisa dilihat dari segi sosial masyarakat. Selanjutnya akan diuraikan secara lebih dalam pada pembahasan dibawah ini. 


\section{Perubahan Sikap/Afektif}

Implikasi dari pelaksanaan Outbound terhadap ketrampilan perserta dibidang Bahasa Bali adalah adanya perubahan sikap bahasa dan tata bahasa. Peserta yang kebiasaan sebelumnya dalam berkomunikasi menggunakan Bahasa Indonesia menjadi menggunakan campur kode atau Dwi Bahasa yaitu Bahasa Bali dan Bahasa Indonesia. Perubahan sikap penggunaan Bahasa (afektif) terjadi pada pengucapan salam, menjawab pertanyaan, dan mendiskripsikan sesuatu, sebagai contoh kata salam "selamat sore" berubah menjadi "Rahajeng sore" "Terimakasih" menjadi "suksma". Sedangkan pada saat menjawab dan mendiskripsikan sesuatu terjadi campur kode, peserta yang rata-rata sebelumnya fasih dalam menggunakan Bahasa Indonesia beralih kode menggunakan Bahasa Bali, meskipun Bahasa Bali andap.

Tingkatan-tingkatan Bahasa (Anggah ungguhing Basa) dalam Bahasa Bali memang menjadi salah satu factor kesulitan dan ketakutan sebagaian besar anakanak ketika berbahasa Bali. Perbendaharaan kata yang minim dan ketakutan salah berbicara terutama dengan orang tua dan tokoh Agama atau masyarakat, menjadi alasan utama. Namun melalui kegaiatan Outbond ini siswa mendapatkan pengalaman langsung menggunakan tingkatan-tingkatan Bahasa Bali dan mengetahui kapan situasi penggunaan Bahasa Bali Alus, Bahasa Bali Andap dan Bahasa Bali Kasar.

Peserta menjadi lebih percaya diri menggunakan Bahasa Bali. Anggapan mengenai Penggunaan Bahasa Bali yang sebelumnya dianggap kurang Gaul, dan kuno menjadi hilang. Kepercayaan diri ini tumbuh secara perlahan ketika diberikan motivasi dalam pelaksanaan Outbound, Sebab penggunaan Bahasa Bali adalah menghargai Budaya Bali yang adiluhung. Kebanggan Bahasa Bali yang hingg kini masih belum punah dan dikagumi oleh banyak orang. Penekanan dalam hal Penggunaan Bahasa Bali halus merupakan wujud sikap penghargaan terhadap lawan bicara, terutama dikalangan keluarga dan lingkungan sekitar.

\section{Perubahan kemampuan/kognitif}

Peserta semakin banyak menguasai kosa kata Bahasa Bali (kognitif) yang didapat dialam proses pembelajaran Bashita Paribasa (Pribahasa). Perbendaharaan kata dalam Bahasa Bali berdampak pada kemampuan berbahasa peserta itu sendiri. Bashita Paribasa (Pribahasa) atau permainan kata sangat efektif dalam meningkatkan kemampuan Berbahasa. Pembuatan kalimat yang ditujukan kepada menyindir lawan bicara menjadi pengalaman yang berkesan dalam proses pembelajaran.

Implikasi dibidang Aksara Bali menjadi hal yang paling meningkat secara drastis. Banyak peserta yang sebelumnya buta Aksara Bali kini sudah Bisa (Kognitif). Membaca dan Menulis Aksara Bali adalah hal yang paling ditakuti sebagian siswa kini menjadi materi yang paling digemari untuk dipelajari. hal ini berkat media pembelajaran menggunakan Puzzel Aksara Bali. Dengan konsep bermain sambil Belajar perserta lebih cepat memahami.

\section{Perubahan Psikomotor}

Implikasi dibidang sastra Bali dengan adanya pembelajaran Outbond Bahasa Bali dapat dilihat dengan munculnya bakat-bakat dari para peserta dibidang sastra Bali (psikomotor). Bakat ini muncul secara perlahan seiring berjalannya proses 
pembelajaran. Apresiasi sastra yang diajarkan dan dipraktekan langsung terutama Sastra Bali tradisional pada saat kegiatan Outbond dapat dijiwai langsung oleh peserta. hal ini bisa dilihat dengan kesenangan siswa dalam kegiatan masatua serta menguasi berbagai judul satua yang sebelumnya belum banyak diketahui.Peserta menjadi antusias dalam mengikuti lomba-lomba yang diadakan oleh Berbagai kalangan mulai dari Uneversitas, Pemerintah Kabupaten atau Instansi pada saat momen Ulang Tahun Kota Singaraja.

\section{Sosial}

Hubungan sosial diantara peserta Outbond menjadi harmonis antara ke empat banjar dan tiga Sekolah Dasar di lingkungan Kalianget. Perubahan ini terlihat saat peserta dapat bekerja sama dan saling mendukung dalam kegiatan Outbond. Hubungan ini terjalin secara berkesinambungan dan berdampak positif dalam kegiatan Pembelajaran Bahasa Bali Khususnya pada kelompok Belajar anak-anak di Desa Kalianget. Peserta menjadi saling mengenal dan persahabatan terjalin dengan Baik.

Hubungan sosial anatara guru dan siswa juga terjalin semakin harmonis terutama dalam pengucapan salam sapa dengan Bahasa Bali, Hubungan antara orang tua dengan anak juga mengalami perubahan terutama dari segi komunikasi di rumah dalam kehidupan sehari-hari. Dalam konteks sosial yang lebih luas yaitu dimasyarakat juga mengalami perubahan terutama ketika anak-anak mengikuti kegiatan sembahyang saat Upacara (odalan) di Pura-pura yang ada dilingkungan Desa Kalianget.

\section{SIMPULAN}

Pemerintah Provisi Bali pada tahun 2016 telah merekrut Penyuluh Bahasa Bali yang ditugaskan di seluruh Desa kelurahan di Bali sebagai upaya untuk melestarikan Bahasa Bali dari kepunahan. Penyuluh yang ditugaskan di masingmasing Desa Kelurahan ini mengemban tugas mulia dan misi sebagai garda terdepan dalam pelestarian Bahasa, aksara dan Sastra Bali. Salah satu tugas yang menjadi prioritas adalah mengenalkan Bahasa Bali pada penerasi muda khusnya anak-anak yang semakin meninggalkan Bahasa Bali. Upaya ini diwujudkan melalui pembentukan Kelompok Belajar di masing-masing Banjar atau Dusun dengan bekerja sama dengan pihak Sekolah Dasar dan Pemerintah Desa. namun dalam proses pembentukan kelompok belajar ini berbagai permasalahan ditemukan yakni mulai dari rendah motivasi dan semangat anak-anak dalam Belajar Bahasa Bali, konsep dan model dalam mengajarkan Bahasa Bali yang cendrung membosankan dan menegangkan, minimnya penggunaan Bahasa Bali diranah Keluarga, tidak adanya Guru Bidang Studi Bahasa Bali pada jenjang Sekolah Dasar, serta kurangnya apresiasi dibidang Bahasa, aksara dan Sastra Bali. Melalui evaluasi tersebut Penyuluh Bahasa Bali terutama di Kab. Buleleng mencoba membuat terobosan yang lebih inovatif dalam mengajarkan Bahasa Bali yakni dengan konsep model berlajar sambil bermain atau sering disebut Outbound Bahasa Bali.

Pelaksanaan pembelajaran Outbound Bahasa Bali digagas agar suasana Belajar menjadi lebih menarik, menyenangkan dan anak-anak merasa bergembira namun tetap dengan tujuan utama mengajarakan Bahasa, Sastra dan Aksara Bali. Tempat pelaksanaan Outbound dilangsungkan diluar sekolah yang diikuti oleh Anak-anak SD Kls V yang berasal dari tiga sekolah SD dari empat Banjar Dinas 
dilingkungan Desa kalianget, yang berlangsung setiap minggu di Balai Banjar, Wantilan atau Jaba Pura Desa. Tempat ini dipilih karena keberadaanya sangat strategis berada ditengah-tengah Desa, dan aman dan nyaman dari gangguan. Program Outbound ini mendapat dukungan penuh dari berbagai kalangan, mulai dari Guru Pengajar Bahasa Bali, Kepala sekolah, tokoh adat dan masyarakat, orang tua, serta Pemerintah Desa Kalianget dalam hal ini Perbekel Desa Kalianget, hal ini bisa dilihat dari adaya anggaran pembiayaan melalui Dana Desa mengenai Kelompok Belajar Penyuluh Bahasa Bali untuk membangun dan mewujudkan SDM yang unggul dan berkarakter, serta adanya apresiasi Bagi anak-anak yang berprestasi mampu untuk mewakili Desa dalam ajang lomba-lomba ditingkat Kecamatan. Bentuk pelaksanan Outbound dikemas secara sederhana dengan konsep Dolanan, dan menggunakan media Puzzel aksara yang terbuat dari Kayu, peserta dibagi menjadi kelompok-kelompok dan bersaing untuk menjawab soal yang diberikan. Pada akhir kegiatan kelompok yang mendapatkan scrore tertinggi akan ditetapkan menjadi pemenang dan mendapatkan reward hadiah berupa alatalat tulis, atau makanan ringan, sedangkan kelompok yang kalah akan dihukum untuk bernyanyi tembang Bali.

Implikasi dari kegiatan Pembelajaran Outbound Bahasa Bali ini dibidang Bahasa adalah anak-anak menjadi terbiasa dan percaya diri untuk menggunakan Bahasa Bali dalam berkomunikasi, baik dalam memperkenalkan diri, berbicara dengan orang tua dan Guru disekolah. Anak-anak tidak lagi takut berbicara karena kesalahan penggunaan sor singgih Bahasa Bali, karena sudah paham bahwa sor singgih tersebut adalah untuk menghormati lawan bicara. Implikasi dibidang Aksara Bali adalah munculnya kesenangan peserta dalam membaca dan menulis aksara Bali dengan dilihat ketika lomba-lomba Nyastra Bali (menulis Bali) yang diadakan oleh pemerintah Daerah mampu diikuti oleh anak-anak Desa Kalianget serta pada Bulan Bahasa yang diikuti secara antusias. dibidang Sastra juga mengalami perubahan terutama dalam hal sastra tradisoinal dan Sastra lisan dengan semakin banyaknya Satua (cerita) Bali dan tembang-tembang rare lagu-lagu anakanak semakin dipahami. Dilingkungan masyarakat dalam kehidupan Sosial perubahan atau dampak bisa dilihat dari ruang lingkup penggunaan Bahasa Bali yang sudah semakin dimengerti oleh anak-anak dan orang tua, terutama dilingkunan Pura dan keluaraga, Hubungan siswa antar sekolah semakin harmonis, konflik perkelahian antar sekolah semakin jarang terjadi, anak-anak semakin akrab antar Banjar dan Sekolah.

Berdasarkan hasil penelitian tentunya masih menemukan beberapa kendala dalam proses penelitian, sehingga peneliti memohon saran antara lain: Bagi Guru dan Dosen Bahasa Bali penelitian ini diharapkan meningkatkan pemahaman mengenai pembelajarn Outbound Bahasa Bali. Selanjutnya hasil penelitian ini dapat digunakan sebagai salah satu refrensi untuk penelitian lebih lanjut. Hasil penelitian ini juga diharapkan mampu memotivasi guru untuk mengajar mata pelajaran Bahasa Bali, dan dijadikan alternative bagi kalangan pendidik dilingkup pendidikan formal maupun non formal saat mengajarkan Bahasa Bali.

Bai masyarakat Penelitian ini diharapkan dapat memberikan informasi mengenai proses pelaksanaan Outbound Bahasa Bali serta sistem pelaksanaannya, sehingga dapat dikembangkan dalam berbagai kegiatan-kegiatan non formal seperti pasraman, komunitas, dan kelompok lainnya yang hidup dan berkembang di masyarakat. 
Bagi lembaga Penelitian ini diharapkan dapat memberikan alternatif sehingga dapat mengembangkan metode dan model Belajar kepada calon pengajar baik dalam penyusunan Program Pendidikan formal maupun non formal sehingga dan dapat meningkatkan sumber daya manusia. Bagi peneliti selanjutnya diharapkan untuk bisa melakukan kajian lebih mendalam tentang konsep Pembelajaran Outbound Bahasa Bali, terutama dalam proses dan pelaksanaannya serta ide-ide yang lebih kreatif dan inovatif yang bisa diterapkan didalamnya sehingga Pembelajaran Bahasa Bali terasa lebih menyenangkan bagi anak-anak guna tetap menjaga dan melestarikan Bahasa, Sastra dan Aksara Bali.

\section{DAFTAR PUSTAKA}

Adelia Vera. 2012. Metode Mengajar Anak di Luar Kelas (Outdoor study). Yogyakarta: DIVA Press

Agus Suprijono. 2009. Cooperative Learning, Teori \& Aplikasi PAIKEM. Surabaya: Pustaka Pelajar

Agustinus Susanta, Outbond profesional : pengertian, prinsip perancangan, dan panduan pelaksanaan / Agustinus Susanta: Yogyakarta :

Andrianus dan Yuniarti.2007. Divinisi dan Manfaat Outbound

Anggraeni, N. P. (2019). DOLANAN SEBAGAI MEDIA PENDIDIKAN KARAKTER PADA SISWA SEKOLAH DASAR. Adi Widya: Jurnal Pendidikan Dasar, , 3(1), 1-6.

Asti, Baidatul Muchlisin.2009.Fun Outbound. :Merancang Kegiatan Outbound. yang Efektif.Yogyakarta:Diva Press

Atmaja. 2016, Perkembangan Teknologi Pembelajoran Memulis Aksara Carakan dengan Font Bali Simhar Pada Program Studi Sastra Bali Fakultas Sastra Universitas Udayana. Tesis : Program Pascasarjana IIDN Denpasar.

Azwar. 2005. Sikap Mamusia : Teori dan Pengukurannya. Yogyakarta. Pustaka Pelajar

Bintari, N. K. (2015). Aplikasi Pembelajaran Bahasa Bali Alus Dengan Phonegap (melajah Basa Bali). eProceedings of Applied Science, 1(3).

Bungin, Burhan, 2001. Metodologi Penelition Kualitatir Dan Kuantitatif. Yogyakarta. Gajah Mada Press.

Dalyono. Muhammad 2007. Psikologi Pendidikan. Jakarta: Rineka Cipta.

Dewi, N. K. (2016). ). Pengembangan Video Pembelajaran Berbasis Kearifan Lokal Mata Pelajaran Bahasa Bali Untuk Siswa Kelas III. Jurnal Edutech Undiksha, 4(2).

Dhanawaty, N. M. (2017). Perlunya Pembelajaran Bahasa Bali Yang Rekreatif Di Sekolah Dasar Multikultural Dan Multilingual. Madah, 4(2), 120-130.

diakses pada tgl 16 April 2020 pkl 20:05

Dina Indriana. (2011). Ragam Alat Bantu Media Pembelajaran. Jogjakarta: DIVA Press 
Djamarah, Syaiful Bahri. 2006. Strategi Belajar Mengajar. Jakarta: Rineka Cipta.

Duija, Nengah I. 2006. Agama Hindu Sebagai Bentuk Pemertahanan, Aksara, Bahasa, dan Sastra Bali dalam Dinamika Kehidupan Masyarakat Bali. Makalah yang disampaikan dalam Kongres Bahasa Bali VI di Denpasar.

Dwija, I Wayan. 2003 Metodologi Penelitian Pendidikan. Amlapura : STKIP Agama Hindu

Eka Putra. 2015. Penggunaan Macromedia Flash dalam Memulis Aksara Bali Pada Siswa Kelas VIII SMl Dwijendra Denpasar. Tesis : Program Pascasarjana IHDN Denpasar

Embo, E. (2017). Pengaruh Penerapan Metode Pembelajaran Terhadap Motivasi Belajar Siswa Di Sekolah Menengah Kejuruan Negeri 4 Makassar . . Makassar: Fakultas Ilmu Sosial Universitas Negeri .

Emzir, prof Dr.2007 Metodologi Penelitian Pendidikan. Jakarta : PT Raja Grafindo Persada

Fajaraditya, I. N. ((2013)). Perancangan Media Interaktif Pembelajaran Bahasa Bali Untuk Anak Anak Dengan Load Movie Berbasis Animasi Flash. Jurnal Nasional Pendidikan Teknik Informatika: JANAPATI, 2(1), 51-63.

Falah, N. (2014). Efektivitas Out Bound Sebagai Metode Pembelajaran. HISBAH, 2.

Harjanto, 2005. Perencanaan Pengajaran. Jakarata: Rineka Cipta

Ibrahim, Muhsin dkk. (2000). Pembelajaran Kooperatif. Surabaya: University Press.

Iqbal, Hasan, 2002. Metodologi Penelitian dan Aplikasinya Jakarta: Galia Indonesia.

Jatiyasa, I. W. (2019, August). Pembelajaran Bahasa Bali Di Era Revolusi Industri 4.0 (Peluang Dan Tantangannya). In Prosiding Seminar Nasional Dharma Acarya (Vol. 1, No. 1).

Jendra, 1993. Bahasa Dalam Ketata Bahasaan. Jakarta: PT. Grafindo Persada

Koentjaraningrat. 1991. Metode metode Penelitian Masyarakat. Jakarta: PT Gramedia.

Koentjaraningrat. 2010. Metodelogi Penelitian. Jakarta: Gramedia.

Martinis Yamin dan Maisah, 2009: Manajemen pembelajaran kelas : strategi meningkatkan mutu pembelajaran. Jakarta. GP

Moeslichatoen, R. (1999). Metode pengajaran di taman kanak-kanak. Jakarta: Penerbit Rineka Cipta.

Muhammad, As'adi.2009.The Power of Outbound. Training. Yogyakarta:Power Books(Ihdiana)

Mulyasa. 2010. Menjadi Guru Profesional (Menciptakan Pembelajaran Kreatif dan Menyenangkan). Bandung Rosda. Cetakan kesembilan. 
Mulyono, dan Badiatul Muchlisin Asti.2010. Smart Games for Outbound. Training.Yogyakarta:Diva Press

Peni Susapti. (2010). Pembelajaran Berbasis Alam(Penelitian). Salatiga: Sekolah Tinggi Agama Negeri (STAIN).

Pradipta, I. B. (2015). Pengembangan Aplikasi Game Basa Bali Sebagai Media Pembelajaran Bahasa Bali Berbasis Android. KARMAPATI (Kumpulan Artikel Mahasiswa Pendidikan Teknik Informatika), 4(5), , 571-582.

Purniawati, S. A. (2018). PENYULUH BAHASA B ALI: A LANGUAGE POLICY OF BALI PROVINCIAL GOVERNMENT ON BALINESE MOTHER TONGUE (A CASE STUDY). In The 4th National Conference on Language and Language Teaching (NCOLLT) 2018 is annual conference organized by English Education Department, Faculty of Teacher Training and Education, Universitas PGRI Adi Buana Surabaya., 221.

Rahmawati, E. (2015). Implementasi pendidikan Non formal di Desa Sikayu Kecamatan Buayan Kabupaten Kebumen.

Ristang Sutawijaya. 2008. Super Kreatif Games For Outbound Training.

Rochati, Sri.2011.Program Kegiatan Outbound. Bina Empati sebagai Alternatif Stimulasi Kecerdasan Interpersonal Anak Kelompok Bermain.Tesis.(Tidak diterbitkan).Surakarta:Universitas Muhammadiyah Surakarta

Rocmah, L. I. (2012). Model pembelajaran Outbound untuk anak usia dini. PEDAGOGIA, 182.

Sanjaya, P. ((2020)). FAKTOR-FAKTOR PENGHAMBAT DALAM PELAKSANAAN PASANTIAN SEBAGAI LEMBAGA PENDIDIKAN KEAGAMAAN HINDU NONFORMAL. Haridracarya: Jurnal Pendidikan Agama Hindu, 1(1), 33-36.

Slameto. 2003. Belajar dan Faktor-faktor yang Mempengaruhinya. Jakarta: Rineka Cipta.

Sriwi, R. (2010 ). Pengaruh Metode Outbond Dan Minat Belajar Terhadap Keterampilan Berbicara Siswa (Eksperimen Pada Siswa Kelas Viii Mtsn Kebumen 2 Dan Mtsn Triwarno Kutowinangun Kebumen). Surakarta: Tesis Program Pascasarjana Universitas Sebelas Maret Surakarta.

Suardiana, I. W. (2019). Bahasa Bali dan Pemertahanan Kearifan Lokal. Linguistika :Buletin Ilmiah Program Magister Linguistik Universitas Udayana, 3-4.

Suastra, I. M. (2009). Bahasa Bali Sebagai Simbol Identitas Manusia Bali. Linguistika :Buletin Ilmiah Program Magister Linguistik Universitas

Sugiyono. (2012). Metode Penelitian Pendidikan Pendekatan Kuantitatif, Kualitatif dan $R \& D$. Bandung: Alfabeta.

Sugiyono.2010. Metode Penelitian Kuantitatif, Kualitatif, dan R\&D. Bandung: Alfabeta

Sukmadinata, Syaodih. 2007. Metode Penelitian Pendidikan. Bandung : PT Remaja Rosadakarya 
Sumardianto.2010."pengaruh Outbound. terhadap kecemasan (anxiety)"(online), (http://ainicahayamata.wordpress.com/2010/03/06/jurnal$\%$ E2\%80\%9CpengaruhOutbound.-terhadap-kecemasananxiety\%E2\%80\%9D/diunduh tanggal 6 Desember 2019 pukul 07:36 Wita)

Suryabrata, Smadi. 2002. Psikologi Pendidikan. Jakarta: PT Grafindo Perkasa Rajawali.

Suryadi. (2009). Manajemen Mutu Berbasis Sekolah: Konsep dan Aplikasi. Bandung: PT Sarana Panca Karya

Suryosubroto. (1990). Tatalaksana Kurikulum. Jakarta: Rineka Cipta

Susanta, Agustinus. 2010. Outbond Profesional Pengertian, Prisip Perancangan dan Panduan Pelaksanaan. Yogyakarta: CV Andi Offset (Rahmawati, 2015)

Susilana, Rudi dan Riyana, Cepi. 2009. Media Pembelajaran. Bandung: CV Wacana Prima

Tedjasaputra, Mayke S. (2001). Bermain mainan dan permainan untuk pendidikan Usia dini. Jakarta: Grasindo. Yogyakarta: Cermelang Pulising. 